\title{
CORRESPONDENCE.
}

\section{MR. DEUCHAR'S PAPER ON NEGATIVE POLICY VALUES.}

To the Editor of the Journal of the Institute of Actuaries.

Srr,-The employment, in valuations, of negative policy values is a matter of such vital importance to life assurance offices, that the point raised in Mr. Deuchar's paper, that these will not affect an office valuing septennially so materially as one valuing more frequently, requires to be thoroughly proved before it be admitted; and as I think the arguments urged by him in favour of his proposition entirely inadmissible, perhaps you will allow me to point out wherein, in my opinion, the fallacy of his position lies.

I take two offices, $\mathbf{A}$ and $B$, starting together and each doing an annual new business of 1,000 policies of $£ 300$ each, age at entry 40 , 
premium $\& 9.12 s$, expenses 10 per-cent; both offices to value their gross premiums less 15 per-cent by the Institute tables at 4 per-cent interest, but to allow one third of the premiums paid as a surrender value after payment of three premiums. Then, if the rate of mortality experienced coincide with that to be expected by the Institute tables, and the rate of discontinuance be as assumed in column 2 , the experience of the offices will be represented by the following table:-

\begin{tabular}{|c|c|c|c|c|}
\hline Year. & $\begin{array}{c}\text { Rate of discon- } \\
\text { tmnance. }\end{array}$ & Fintered. & Died. & $\begin{array}{l}\text { Discon- } \\
\text { tinued. }\end{array}$ \\
\hline 1 & $\cdot 060$ & 1,000 & 10 & 60 \\
\hline 2 & .043 & 930 & 10 & 40 \\
\hline 3 & .039 & 880 & 9 & 34 \\
\hline 4 & 033 & 837 & $\mathbf{9}$ & 28 \\
\hline 5 & .030 & 800 & 9 & 24 \\
\hline 6 & -026 & 767 & 9 & 20 \\
\hline 7 & .024 & 738 & 10 & 18 \\
\hline 8 & .021 & 710 & 10 & 15 \\
\hline 9 & .019 & 685 & 10 & $\mathbf{1 3}$ \\
\hline 10 & +017 & 662 & 10 & 11 \\
\hline 11 & .015 & 641 & 10 & 10 \\
\hline 12 & .014 & 621 & 10 & 9 \\
\hline 13 & .012 & 602 & 11 & 7 \\
\hline 14 & .012 & 584 & 11 & 7 \\
\hline
\end{tabular}

Let $A$ value annually, and $B$ septennially. The above-mentioned mode of valuation will have the effect of giving negative values to all policies for the first three years, and of making a reserve insufficient to pay the surrender value for a further period of three years. Now, assuming ail the premiums due on, say, Ist January, and the claims all paid during the year, but the lapses and surrenders not to be notified to the office until the 1st January following, if the valuation be made on 31st December, the number of policies to be valued will be equal to the number of entrants of the year, less the deaths therein; and the full effects of taking credit for negative values will be felt, for the office will reekon as assets ail the policies of less than three years' standing, some of which will lapse next day, and for many others it will make a reserve too small to pay the surrender value to be allowed on the morrow. The reserve in each year made by $A$ will be as follows :-

\begin{tabular}{|c|c|c|c|}
\hline $\begin{array}{l}\text { Age of } \\
\text { policies. } \\
\text { Years. }\end{array}$ & $\begin{array}{l}\text { No. of } \\
\text { policies valned. }\end{array}$ & $\begin{array}{c}\text { Value } \\
£\end{array}$ & $\begin{array}{c}\text { Reserve. } \\
\&\end{array}$ \\
\hline $\begin{array}{l}\text { Years. } \\
\mathbf{1}\end{array}$ & 990 & $-18,151$ & $-19,151$ \\
\hline 2 & 920 & $\begin{array}{r}-7,877 \\
-\quad 787\end{array}$ & $\begin{array}{r}-21,028 \\
-\end{array}$ \\
\hline 3 & 871 & $-\quad 3,209$ & $-24,237$ \\
\hline 4 & 828 & $+1,103$ & $-23,134$ \\
\hline 5 & 791 & 5,123 & $-18,011$ \\
\hline 6 & 758 & 8,880 & - 9,131 \\
\hline 7 & 728 & 12,381 & $\begin{array}{l}+3,250 \\
\end{array}$ \\
\hline 8 & 700 & 15,658 & 18,908 \\
\hline 9 & 675 & 18,780 & 37,688 \\
\hline 10 & 652 & 21,752 & 59,440 \\
\hline 11 & 631 & 24,622 & 84,062 \\
\hline 12 & 611 & 27,378 & 111,440 \\
\hline 13 & 591 & 29,973 & 141,413 \\
\hline \multirow[t]{3}{*}{14} & 573 & 32,491 & 173,904 \\
\hline & & $\begin{array}{r}+198,141 \\
173,904\end{array}$ & \\
\hline & & $-\overline{24,237}$ & \\
\hline
\end{tabular}

And the premiums received, claims, surrenders, and expenses, paid as in the following table: 
1876.]

\begin{tabular}{|c|c|c|c|c|}
\hline Year. & Premiunss. & Claims. & Surrenders, & Inpenses \\
\hline * & 63,955 & $2 z, 800$ & $1, \stackrel{*}{062}$ & 6,396 \\
\hline 9 & 70,531 & 25,800 & 1,350 & 7,053 \\
\hline 10 & 76,886 & 28,800 & 1,641 & 7,689 \\
\hline 11 & 83,040 & 31,800 & 1,923 & 8,304 \\
\hline 12 & 89,002 & 34,800 & $\mathbf{2 , 2 1 0}$ & 8,900 \\
\hline 13 & 94,781 & 38,100 & $\mathbf{2 , 4 9 9}$ & 9,478 \\
\hline & & & & \\
\hline
\end{tabular}

Suppose $4 \frac{1}{2}$ per-cent to be the rate of interest at which the average of the funds at the beginning and end of the year is invested, and let us follow the proceedings of both offices from the commencement of the 2nd septennium, both beginning the year with funds in hand amounting to $£ 3,250$, to meet a valuation showing positive values of $£ 27,487$, and negative values of $£ 24,237$, and we shall find the results to be as follows :-

\begin{tabular}{|c|c|c|c|c|}
\hline \multirow[b]{2}{*}{ Year. } & \multicolumn{3}{|c|}{ A. } & \multirow{3}{*}{$\begin{array}{l}\text { Amount } \\
\text { divided. } \\
\qquad\end{array}$} \\
\hline & $\begin{array}{l}\text { Funds, } \\
\text { Ist Jan. }\end{array}$ & $\begin{array}{l}\text { Funds, } \\
\text { 31st Dec }\end{array}$ & Reserve. & \\
\hline & t & E & $£$ & \\
\hline 8 & 3,250 & 37,872 & 18,908 & 18,964 \\
\hline 9 & 18,908 & 56,943 & 37,688 & 19,255 \\
\hline 10 & 37,688 & 79,071 & 59,440 & 19,631 \\
\hline 11 & 59,440 & 104,133 & 84,062 & 20,071 \\
\hline 12 & 84,062 & 132,016 & 111,440 & 20,576 \\
\hline 13 & 111,440 & 162,303 & 141,413 & 20,890 \\
\hline 14 & 141,4113 & 195,189 & 173,904 & 21,285 \\
\hline \multicolumn{5}{|c|}{ B. } \\
\hline & Year. & $\begin{array}{c}\text { Funds, 1st Jan. } \\
\qquad\end{array}$ & \multicolumn{2}{|c|}{ Funds, 31st Dec. } \\
\hline & 8 & 3,250 & \multicolumn{2}{|c|}{37.872} \\
\hline & 9 & 37,872 & \multicolumn{2}{|c|}{76,780} \\
\hline & 10 & 76,780 & \multicolumn{2}{|c|}{119,963} \\
\hline & 11 & 119,963 & \multicolumn{2}{|c|}{167,443} \\
\hline & 12 & 167,443 & \multicolumn{2}{|c|}{219,235} \\
\hline & 13 & 219,235 & \multicolumn{2}{|c|}{275,061} \\
\hline & 14 & 275,061 & \multicolumn{2}{|c|}{$\mathbf{3 3 4}, 990$} \\
\hline
\end{tabular}

Now, the amount of B's reserve at the end of the period will be the same as A's, and B will therefore distribute as profit (£334,990

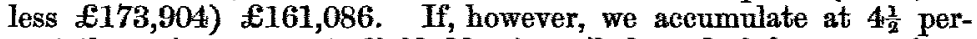
cent the various amounts divided by $A$ until the end of the septennium, we shall find that they fall short of the amount now divided by $B$ by \&494; and the reason for this apparent deficiency is somewhat curious. The amount that $A$ divides at the end of the 8 th year is retained by $B$ and forms part of those funds whose average amount at the beginning and end of the year is invested at $4 \frac{7}{3}$ per-cent, so that if $m$ be the amount distributed by $A$, and $n$ its amount at the end of the year, $i$ being the rate of interest, we have-

whence

$$
\begin{gathered}
\frac{m+n}{2} \times i=n-m, \\
n\left(1-\frac{i}{2}\right)=m\left(1+\frac{i}{2}\right), \\
n=m \frac{1+\frac{i}{2}}{1-\frac{i}{2}} .
\end{gathered}
$$


If $i=\cdot 045$, we have $n=m \times 1.046036$;

so that the amounts divided by $A$ must be invested at 4.6036 percent to amount to the sum now divided by $B$, since that is the rate $B$ has made on these sums it has hitherto retained.

$\begin{array}{rccc}\text { Year. } & \text { Sum divided } & \text { Amount at } & \text { Amount at } \\ & \text { by A. } & 4 \cdot 5 \text { per-cent. } & 4 \cdot 6036 \text { per-cent. } \\ 8 & \mathbb{E} & \mathbb{E} & \mathbb{E} \\ 9 & 18,964 & \mathbf{2 4 , 6 9 6} & \mathbf{2 4 , 8 4 4} \\ 10 & \mathbf{1 9 , 2 5 5} & \mathbf{2 3 , 9 9 5} & \mathbf{2 4 , 1 1 5} \\ 11 & \mathbf{1 9} 631 & \mathbf{2 3 , 4 1 1} & \mathbf{2 3 , 5 0 3} \\ 12 & 20,071 & \mathbf{2 2 , 9 0 5} & \mathbf{2 2 , 9 7 3} \\ 13 & 20,576 & 22,470 & \mathbf{2 2 , 5 1 4} \\ 14 & 20,890 & 21,830 & \mathbf{2 1 , 8 5 2} \\ & 21,285 & \mathbf{2 1 , 2 8 5} & \mathbf{2 1 , 2 8 5} \\ & & \underline{160,592} & \mathbf{1 6 1 , 0 8 6}\end{array}$

At first sight it would appear that A would distribute a larger amount than B, since, in each of the seven years, policies in the former office bearing negative values have been discontinued and the surplus shown by their means already distributed in eash; but a little consideration will show that this is not the case. The first year of the septennium A starts with assets of $£ 3,250$ in cash and $£ 24,237$ in negative values, against a positive liability of $£ 27,487$. Certain of these negative values turn out illusory, the policies representing them not being kept up; but as the liability originally set against them remains, there is a deficiency at the end of the year which has to be made good out of any actual profit A may have made during the year on its older polieies. Then, in order to balance the account and to declare a bonus, $\mathbf{A}$ swells its funds with a fresh amount of negative values on which similar losses are incurred in the ensuing year, and have to be defrayed in like manner. The fundamental error in this argument is in supposing that A can distribute as profit cash in hand, and set negative values against positive liabilities without having in the following year to repay with interest the loss arising out of its negative values before the office proceeds to make another division. $B$ in the early part of the septennium suffers the same losses as A, through taking into account the negative values with which they both begin the period under observation; but as $\mathbf{B}$ makes no valuation and no distribution, it does not make the profit which A claims to do, and consequently does not incur the losses that $\mathbf{A}$ suffers, but goes on year by year increasing its funds until the end of the septennium, when it has a surplus aceording to the method of valuation employed, of $£ 136,849$ ( $\$ 334,990$ less a positive liability of $£ 198,141$ ); but not satisfed with this $B$ swells its funds-or what comes to the same thing, reduces its liability -by the same amount of negative values, $£ 24,237$, that A makes use of in the same year, and divides $£ 161,086$, a sum as I have shown above, equal in amount to the several sums divided by A during the septennium.

$$
\text { I am, Sir, your obedient servant, }
$$

5 Whitehall, S.W., $\quad$ W. T. GRAY. $2 \mathrm{Feb} .1876$. 